\title{
The igneous provinciality in Taiwan: consequence of continental rifting superimposed by Luzon and Ryukyu subduction systems
}

\author{
Sun-Lin Chung, ${ }^{*} \ddagger$ T. Frank Yang, ${ }^{*}$ Chi-yu Lee* and \\ Cheng-Hong Chen*
}

*Department of Geology, National Taiwan University, 245 Choushan Road, Taipei, Taiwan, Republic of China; and †Géosciences Rennes, Université de Rennes 1, 35042 Rennes Cedex, France

\begin{abstract}
Geochemical characteristics of late Cenozoic volcanics in Taiwan demonstrate that these rocks were produced in diverse tectonic environments. In Taiwan, three igneous provinces, namely, Western, Eastern and Northern, respectively (in order of the initiation of volcanic activities), can be distinguished. The Western Province comprises intraplate basalts, erupted in the rifted continental margin of southeastern China; whereas the Eastern and Northern Provinces are composed of arc volcanics genetically related to the Luzon and the Ryukyu subduction zones, respectively. These volcanic rocks were sequentially emplaced on the island of Taiwan as a result of the collision between the Luzon arc and the Asian continent since about $12 \mathrm{Ma}$. This collision, likewise, induced westward migration of the Ryukyu Trench system and subsequent opening of the Okinawa Trough. As a consequence, the collision-derived compression diminished in northern Taiwan. A post-collisional extension regime thus formed has generated some recent volcanic rocks in this region.
\end{abstract}

\section{Introduction}

The active mountain belt of Taiwan was created by the collision between the Luzon arc and the Asian continent (Chai, 1972; Bowin et al., 1978; Ho, 1986; Teng, 1990). This collision is the major event in the late Cenozoic geodynamic history of the Ryukyu-TaiwanLuzon area (Fig. 1). In the Taiwan orogen, late Cenozoic volcanic rocks are widespread and characterized by a great diversity of rock types, presumably generated in different tectonic settings. They include intraplate basalts, island arc andesites, mid-ocean-ridge derived ophiolites and ultrapotassic rocks formed by postcollisional extension.

In Taiwan, three igneous provinces, namely the Western, Eastern and Northern Provinces (Fig. 2), have been recognized by Yen (1958). Liu and Wang (1982) illustrated the geographic distribution of these provinces and discussed general tectonic implications. It was shown that each province reflects a unique tectonic environment around Taiwan (Table 1). In the last decade, numerous geochemical studies of the volcanic rocks have been carried out with the purpose of understanding the processes of magma genesis along with the geodynamic evolution of the island.

In this paper, we first provide a review of the geotectonic framework of Taiwan. Then, a scheme of the igneous provinces will be presented and chemical and isotopic characteristics of the volcanic rocks will be summarized. Finally, following the arc-continent collision model proposed by Teng (1990), we shall discuss the tectonomagmatic evolution in Taiwan with emphasis on the temporal and spatial relationships between the late Cenozoic magmatism and the geotectonic environment.

\section{Geotectonic Framework}

The continental margin of southern China has been a rifted margin since the late Cretaceous (Taylor and Hayes, 1980; Ru and Piggot, 1986). This is evidenced by the occurrence of many Tertiary grabens and halfgrabens in the Taiwan Strait and western Taiwan, as revealed by studies of seismostratigraphy and deep drilling down to about $6 \mathrm{~km}$ depth (Sun, 1985; Sun and Hsu, 1991). The rifting around the Taiwan Strait, which gave rise to episodic emplacement of intraplate basalts (Fig. 1), is generally considered to be related to the opening of the South China Sea. This rifting probably began in the late Eocene and resulted in major subsidence accompanied by graben formation in the early Oligocene (Teng et al., 1991). It ceased due to the westward compression resulting from the arc-continent collision since about $12 \mathrm{Ma}$ (Teng, 1990). This collision has not only created the orogen in Taiwan but also triggered westward encroachment of the Ryukyu Trench system that initiated the arc volcanism in northern Taiwan (Suppe, 1984; Teng et al., 1992).

The Taiwan orogen is sitting on the boundary between the Philippine Sea plate and the Asian plate (Fig. 1). The Longitudinal Valley Fault in eastern Taiwan is believed to be the geologic suture (Fig. 2). To the east, the coastal Range represents the accreted northern tip of the Luzon arc. It consists of arc volcanics and sedimentary sequences; the latter comprise rocks from the pre-collisional Luzon arc-Manila Trench system overlain by syn-collisional orogenic sediments (Teng, 1987). To the west, metamorphic and sedimentary rocks of the deformed southeastern China margin are exposed. The Tananao metamorphic complex of the 


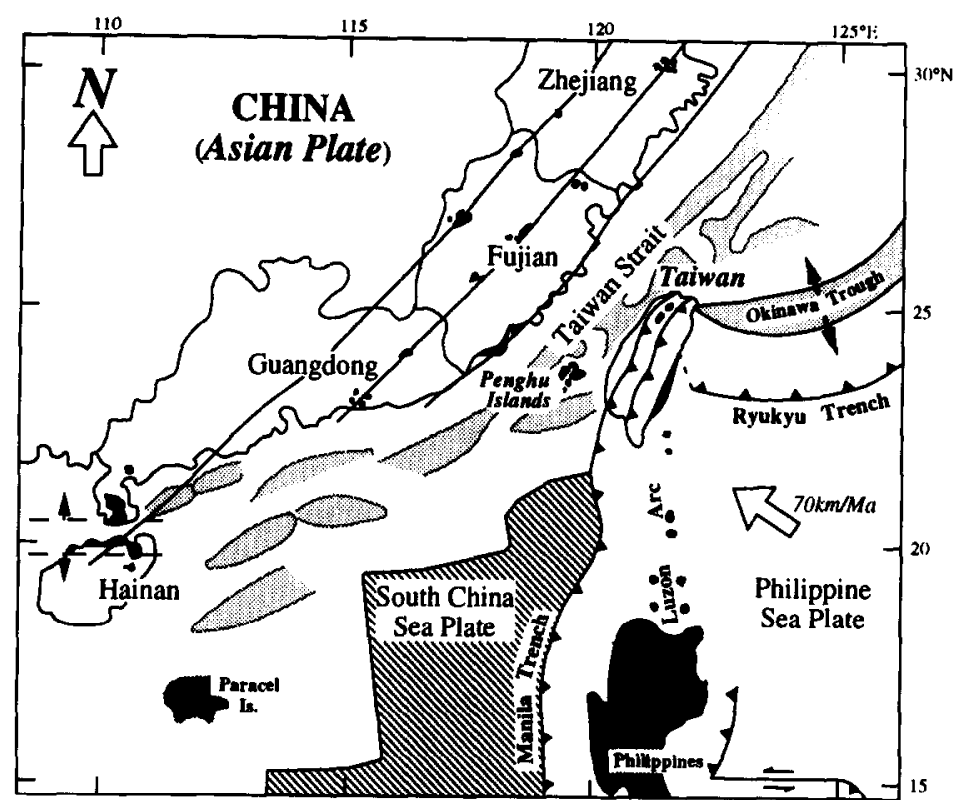

Fig. 1. Generalized map showing the geotectonic framework around Taiwan. Sedimentary basins and intraplate basalts resulting from the Cenozoic extension in the south China continental margin are shown by shaded and black areas, respectively. Modified from Suppe (1981), Ho (1986), Teng (1990) and Chung et al.

(1994).

Central Range can be regarded as uplifted and unroofed continental basement. The Slate Terrane and the Western Foothills, both composed of Tertiary sequences, represent the overlying sedimentary cover (Chai, 1972; Ho, 1986; Teng, 1990). Further to the west, the Coastal Plain and the Taiwan Strait are underlain mainly by undeformed Cenozoic sedimentary sequences (Sun, 1985).

The Philippine Sea plate is subducting underneath the Asian plate at the Ryukyu Trench and overriding the South China Sea plate at the Manila Trech (Fig. 1). A change of the motion of the Philippine Sea plate at about $5 \mathrm{Ma}$ (Seno and Maruyama, 1984) has been thought to be closely related to the arc-continent collision in Taiwan, and probably has induced westward migration of the subducting boundary of the Philippine Sea plate (Suppe, 1984). As a consequence, the Ryukyu Trench system extended southwards to northeastern Taiwan in association with subsequent backarc spreading (i.e. opening of the Okinawa Trough; Fig. 1). The northeastern part of Taiwan hence has switched from the collisional environment to the Ryukyu subduction scheme in the last 3 million years (Suppe, 1984; Teng et al., 1992). Therefore, Taiwan is not only a collision zone between the Luzon arc and the Asian continent, but also a transitional region between the opposing Ryukyu and Luzon subduction systems.

\section{The Igneous Provinces in Taiwan}

\section{Western Province}

The Western Province consists of intraplate basalts emplaced in the southeast China rifted margin. The intraplate volcanism probably began in the early Tertiary and was most active in the Miocene time (Zhou and Chen, 1981; Chen, 1990). The early Tertiary volcanics occur sporadically in the sedimentary sequences in the Taiwan Strait (Sun, 1985; Sun and Hsu, 1991). Only late Cenozoic basalts have been exposed on land; as lava flows and pyroclastics in Fujian (mainland China), Penghu Islands (in the Taiwan Strait) and northwestern Taiwan, respectively (Fig. 1). Overall, these basalts display a spatial variation in chemical and isotropic compositions that could be explained as a result of the interaction between the lithosphere and the asthenosphere during continental rifting (Chung et al., 1994).

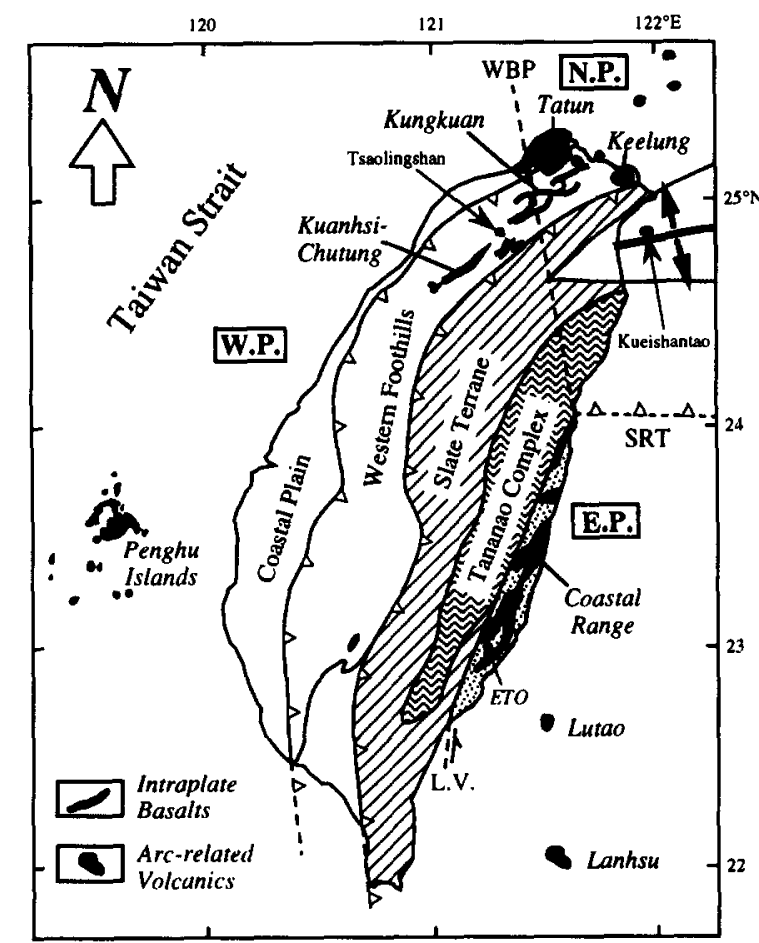

Fig. 2. Igneous provinces and major geotectonic units in Taiwan. W.P. = Western Province; E.P. = Eastern Province; N.P. = Northern Province; ETO = East Taiwan Ophiolite; L.V. = Longitudinal Valley; $\mathbf{W B P}=$ western boundary of Philippine Sea plate; SRT = seismological Ryukyu Trench. Summarized from Tsai et al. (1977), Bowin et al. (1978), Ho (1982) and Liu and Wang (1982). 
Table 1. Igneous provinces in Taiwan and their generalized characteristics

\begin{tabular}{|c|c|c|c|c|c|}
\hline Province & Tectonic setting & Major locality & Age (Ma) & Main rock & References \\
\hline Western & $\begin{array}{r}\text { Conti } \\
\text { rifti }\end{array}$ & Is & $\begin{array}{l}16-8 \\
23-20 \\
13-9\end{array}$ & $\begin{array}{l}\text { Basalt } \\
\text { Basalt } \\
\text { Basalt }\end{array}$ & $\begin{array}{l}\text { Chen and Chung (1985); Juang (1988); } \\
\text { Chen (1990); Lee (1990 and unpublished data); } \\
\text { Chung et al. (1995a) }\end{array}$ \\
\hline Eastern & $\begin{array}{l}\text { Luzon } \\
\text { subduction } \\
\text { South China Sea } \\
\text { spreading }\end{array}$ & $\begin{array}{l}\text { Coastal Range } \\
\text { Lutao and Lanhsu } \\
\text { Kuanshan } \\
\quad \text { (Lichi Mélange) }\end{array}$ & $\begin{array}{l}>16-4 \\
>3.5-0.5^{*} \\
\quad \sim 15\end{array}$ & $\begin{array}{l}\text { Andesite } \\
\text { Andesite } \\
\text { Ophiolite }\end{array}$ & $\begin{array}{l}\text { Juang and Bellon (1984); Yang et al. (1988, 1992); } \\
\text { Yang (1992); Lo et al. (1994) } \\
\text { Liou et al. (1977); Suppe et al. (1981); } \\
\text { Jahn (1986); Chung and Sun (1992) }\end{array}$ \\
\hline Northern & $\begin{array}{l}\text { Ryukyu } \\
\text { subduction }\end{array}$ & $\begin{array}{l}\text { Tatun Volcanoes } \\
\text { Keelung Volcanoes } \\
\text { Offshore Islets }\end{array}$ & $\begin{array}{l}2.8-0.2 \\
1.7-0.8 \\
2.1-1.6\end{array}$ & $\begin{array}{l}\text { Andesite } \\
\text { Andesite } \\
\text { Andesite }\end{array}$ & $\begin{array}{l}\text { Chen (1978); Chen (1989); } \\
\text { Juang and Chen (1989); Wang and Chen (1990); } \\
\text { Chen (1990) }\end{array}$ \\
\hline Recent & $\begin{array}{l}\text { Post-collisional } \\
\text { extension }\end{array}$ & $\begin{array}{l}\text { Kueioshantao } \\
\text { Tsaolingshan }\end{array}$ & $\begin{array}{l}<0.1 \\
\leqslant 0.2\end{array}$ & $\begin{array}{l}\text { Andesite } \\
\text { Absarokite }\end{array}$ & $\begin{array}{l}\text { Chang and Chen (1979); Chen (1983); Chen (1989); } \\
\text { Juang and Chen (1989) }\end{array}$ \\
\hline
\end{tabular}

* In Hsiaolanhsu, a small islet near Lanhsu, the volcanism may have lasted until recently (<0.1 Ma; Yang, 1992).

The Penghu Islands are composed of 63 basaltic islets with a total area of about $120 \mathrm{~km}^{2}$ above the sea level. The basaltic volcanism lasted from 16 to $8 \mathrm{Ma}$ (Table 1) and resulted in alternating flows of alkali basalts and tholeiites in many localities. Generally, tholeiites constitute the bulk of the islands. They all display element abundance patterns typical of OIB (ocean island basalt) (Fig. 3a), resembling other Cenozoic basalts around the South China Sea (Tu et al., 1991, 1992). Likewise, alkali basalts and tholeiites in the Penghu Islands have virtually indistinguishable isotopic compositions (Fig. 4a), suggesting that they originated from a rather homogeneous mantle source through different degrees of melting (Chung et al., 1994).

In NW Taiwan, basalts occur as lenticular bodies in Neogene sedimentary sequences of the Western Foothills (Fig. 2). The sequences, presently constituting a part of the fold-and-thrust belt of Taiwan (Suppe, 1981; Dahlen et al., 1984), have been transported about $200 \mathrm{~km}$ northwestly and squeezed up to the present position by the arc-continent collision (Suppe, 1981, 1984; Teng, 1990). Two major stages of basalt emplacement, the Kungkuan

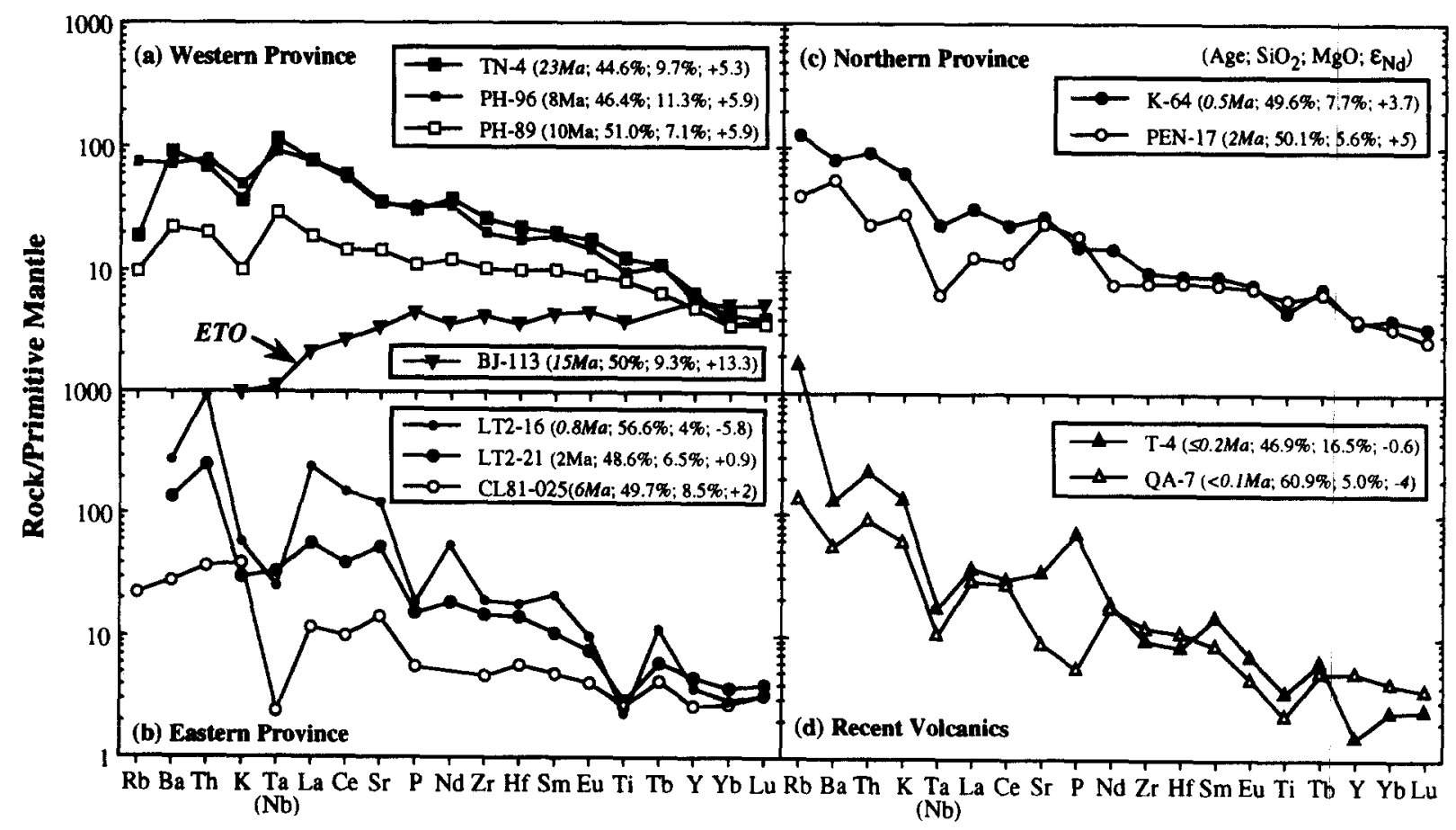

Fig. 3. Spidergrams of the late Cenozoic volcanic rocks in Taiwan. Except for two samples (LT2-16 and QA-7), basaltic rocks from different igneous provinces are shown through the plots. They include: (a) TN-4, alkali basalt from the Kungkuan area; PH-96, alkali basalt from Penghu Islands; PH-89, tholeiite from Penghu Islands; BJ-113, basalt of the East Taiwan Ophiolite; (b) CL81-025, tholeiitic basalt from Wushipi, central Coastal Range; LT2-21, high-Al basalt from Lutao; LT2-16, andesite from Lutao; (c) PEN-17, high-Al basalt from Pengchiahsu (an offshore islet); K-64, cal-alkaline basalt from the Tatun Volcano Group; (d) T-4, absarokite from Tsaolingshan; QA-7, andesite from Kueishantao. Note that the East Taiwan Ophiolite basalt is shown in (a) for clarity. Further chemical data are given in parentheses and italicized if representing synthesized values. Data are from Jahn (1986), Chen (1989), Chen (1990), Chen et al. (1990), Yang (1992) and Chung et al. (1995; and unpublished data). The primitive mantle normalizing values are taken from Sun and McDonough (1989). 


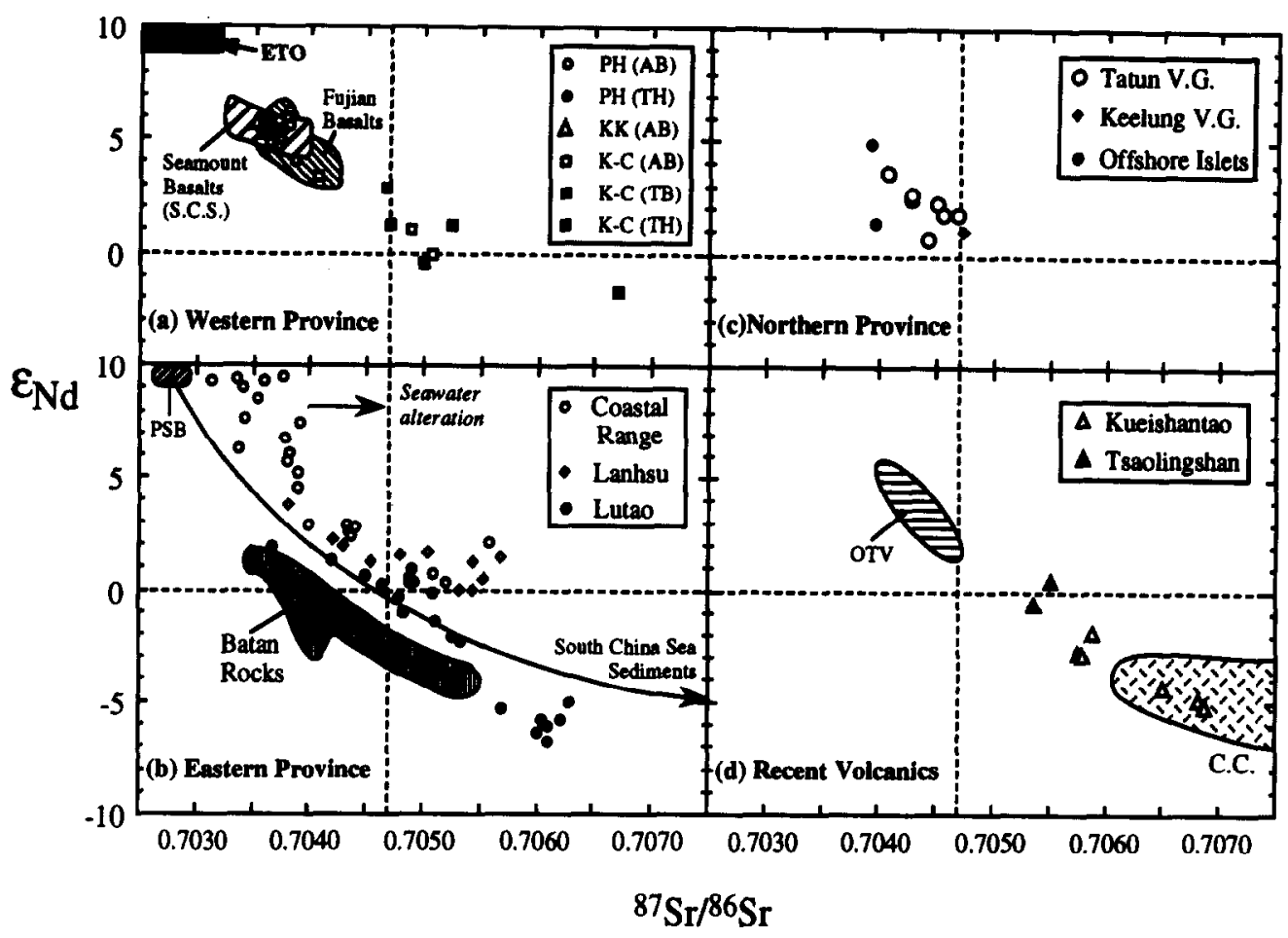

Fig. 4. Sr-Nd isotopic plots of the late Cenozoic volcanic rocks in Taiwan. Data are from Jahn (1986), Chen (1989), Chen et al. (1990), Yang (1992) and Chung et al. (1995; and unpublished data). Sources for the comparison field are as follows: (a) seamount basalts from the South China Sea-Tu et al. (1992), Fujian basalts-Chung et al. (1994); (b) PSB (western Philippine Sea basalts)-Hickey-Vargas (1991), Batan volcanics and xenoliths-McDermott et al. (1993); (d) OTV (Okinawa Trough volcanics)-Auzende et al. (1990), C.C. (continental crust of southeast China)-Lan (1989) and Cheng Hong et al. (1990).

Stage and the Chiaopanshan Stage (Yen, 1958), have been proposed. In general, they are represented by the volcanic activities in the Kungkuan (23-30 Ma) and the Kuanhsi-Chutung (13-9 Ma) areas, respectively (Fig. 2 and Table 1). The Kungkuan volcanics comprise overwhelmingly alkali basalts; whilst rocks in the Kuanhsi-Chutung area show a wide range of compositions including basanite, alkali basalt, transitional basalt and tholeiite (Chen and Chung, 1985). All these basalts exhibit coherent OIB-type chemical characteristic (Fig. 3a) but variable isotopic compositions (Fig. 4a). The early Miocene Kungkuan basalts have uniform $\mathrm{Sr}$ and $\mathrm{Nd}$ isotopic ratios that are identical to those of the Penghu basalts. In Fig. 4a, they plot within the range of the intraplate basalts in Fujian, showing isotopic composition similar to seamount basalts from the South China Sea (Tu et al., 1992). In contrast, the Kuanhsi-Chutung basalts reveal distinct isotope characteristics (Fig. 4a). The significantly higher ${ }^{87} \mathrm{Sr} /{ }^{86} \mathrm{Sr}$ and lower ${ }^{143} \mathrm{Nd} /{ }^{144} \mathrm{Nd}$ ratios of these late Miocene basalts indicate that an additional source component is required in the magma genesis. Most recently, based on new $\mathrm{Pb}$ isotopic data, Chung et al. (1995) document this component to be an EM1-type (as defined by Zindler and Hart, 1986) mantle source. This finding makes the Kuanhsi-Chutung basalts the first convincing group of known volcanics showing EM1 isotope signatures in South China and adjacent areas.

Chung et al. (1994) proposed a continental rifting model of lithosphere thinning and asthenosphere upwelling beneath the Taiwan Strait in the Miocene time. According to this model, the "homogeneous" Kungkuan basalts (23-20 Ma) can be interpreted as decompressional partial melts originating from the asthenospheric convecting mantle. On the other hand, the chemically and isotopically heterogeneous basalts in the Kuanhsi-Chutung area (13-9 Ma) may represent contaminated asthenospheric melts that have interacted to various degrees with the overlying lithosphere during ascent (Chung et al., 1995). This secular change of basalt chemistry in NW Taiwan, which was located near the southeasternmost part of the Asian continental margin in the Miocene time, may be attributed to the onset of the arc-continent collision (i.e. at about $12 \mathrm{Ma}$ ). Since then, the collision-derived compression may have stagnated the magma ascent that could heat up and trigger melting of the lithosphere. The compression finally terminated the intraplate volcanism.

\section{Eastern Province}

The Eastern Province, lying to the east of the Longitudinal Valley Fault, comprises predominantly arc volcanics in the Coastal Range and on the Lutao and Lanhsu islets (Fig. 2). These volcanics were emplaced since at least $16 \mathrm{Ma}$ until the late Quaternary (Table 1). They constitute the backbone of the northern Luzon arc. The most dominant rock type is andesitic pyroclastics with compositions ranging from tholeiitic to high-K calc-alkaline series (Chen, 1990; Yang, 1992). All volcanics in this province, except rocks of the East Taiwan Ophiolite (Fig. 2), show depletion of high field strength elements (HFSE; e.g. $\mathrm{Ta}, \mathrm{Nb}, \mathrm{Ti}$ ) indicative of an arc-related origin (Fig. 3b). In addition, they exhibit heterogeneous isotope characteristics with $\epsilon_{\mathrm{Nd}}$ values varying from +10 to -7 (Fig. $4 \mathrm{~b}$ ). A temporal variation in chemical and isotopic compositions of these arc rocks (i.e. increase of alkalinity and ${ }^{87} \mathrm{Sr} /{ }^{86} \mathrm{Sr}$ ratios 
and decrease of ${ }^{143} \mathrm{Nd} /{ }^{144} \mathrm{Nd}$ ratios) has been documented (Chen, et al., 1990; Defant, et al., 1990; Yang, 1992).

In general, this temporal chemical and isotopic variation can be attributed to involvement of continental sediments in the magma geneses when the Luzon arc progressively approached the Asian continent (Defant et al., 1990). Excluding the effect of seawater alteration, $\mathbf{S r}-\mathbf{N d}-\mathrm{O}$ isotope systematics suggest an origin for most rocks via appropriate degrees of mixing between the depleted mantle of the western Philippine Sea and the subducted sediments from the South China Sea (Chen et al., 1990; Yang, 1992). Certain volcanics in the Lutao islet show the highest $\mathrm{Sr}$ and the lowest $\mathrm{Nd}$ isotopic ratios plotting below the possible mantle-sediment mixing curve (Fig. 4b). Moreover, they have highly enriched LILE (large ion lithophile element; e.g. $\mathrm{Ba}, \mathrm{Th}, \mathrm{U}$ ) and LREE (light rare earth element; e.g. La and Ce) abundances (Fig. 3b). Such characteristics indicate incorporation of additional source component(s), rather than the binary mixing, in the magma generation. To explain the unusual $\mathrm{Sr}-\mathrm{Nd}$ isotopic array defined by these Lutao samples and rocks from the Batan island (Fig. 4b), Chen et al. (1990) suggested the involvement of an EM1-type mantle source which has never been found before in a modern island arc setting. However, based mainly on new $\mathrm{Pb}$ isotopic evidence, McDermott et al. (1993) discard this suggestion and proposed an alternative "subduction component" of slab-derived hydrous fluid. Yang (1992), through a systematic field survey coupled by chronological, chemical and isotopic studies, emphasized the highly LILE-enriched character of the Lutao volcanics (e.g. La and Th reach 300 and 1000 times of the primitive mangle values, respectively; Fig. $3 \mathrm{~b}$ ). $\mathrm{He}$ therefore suggested the contribution of low-degree partial melts from the continental lower crust (of mafic granulite composition) to account for the generation of these distinctive arc volcanics. It is further postulated that this enrichment event related to lower crustal melting which took place rather recently $(<1 \mathrm{Ma})$, resulting probably from the particular tectonic position of Lutao islet where the southeastern China lithosphere is likely to have been underthrusted beneath the Luzon arc (Yang, 1992).

The East Taiwan Ophiolite, consisting of glassy basalts, dolerites, gabbros and serpentinized peridotites as blocks in the Neogene melange in the western part of the Coastal Range (Liou et al., 1977), is an exotic rock suite in the Eastern Province. Since Shih et al., (1972), who first recognized the "oceanic" character of these rocks and suggested a name of "Coast Range Ophiolite of Taiwan", numerous petrological, geochemical and isotopic studies have been carried out (see Chung and Sun, 1992; for a review). Overall geochemical and isotopic characteristics, such as the MORB (mid-oceanic ridge basalt) type elemental abundances (Fig. 3a) and $\mathrm{Nd}$ isotope compositions of the glassy basalts $\left(\epsilon_{\mathrm{Nd}} \approx 13-9 ;\right.$ Jahn, 1986), argue for a mid-ocean or marginal basin origin for the East Taiwan Ophiolite. Together with the geotectonic consideration, the ophiolite is widely believed to have originated from the mid-ocean region of the South China Sea. The rocks were incorporated into the Manila Trench-Luzon arc system, through subduction of the South China Sea plate underneath the Philippine Sea plate (Fig. 1), as allochthonous fragments in the mélange; and finally em- placed at their present location as a result of the arc-continent collision (Suppe et al., 1981). Because of lack of drilling projects in the South China Sea, the well-studied East Taiwan Ophiolite is currently the best material for investigating the structure and chemistry of the ocean floor. Moreover, it provides important chemical and isotopic information of the convecting upper mantle in South China, which offers clues for understanding the relationship between Cenozoic continental rifting, mantle dynamics and intraplate volcanism around this region (Chung and Sun, 1992; Tu et al., 1992; Chung et al., 1994).

\section{Northern Province}

In the Northern Province, volcanic rocks occur in the northern tip of Taiwan and the offshore region (Fig. 2). The magmatism, as compared to that occurring in the Western and Eastern Provinces, is relatively juvenile and short-lived (2.8-0.2 Ma; Table 1). Two main volcanic fields (namely, the Tatun and the Keelung Volcano Groups), as well as the offshore islets, are composed of andesitic pyroclastics and flows with minor basalts (Chen, 1990; and references therein). These rocks are also characterized by HFSE depletions in spidergrams (Fig. 3c), indicating a subduction-related origin. In contrast to volcanics in the Eastern Province, they show rather restricted $\mathrm{Sr}$ and $\mathrm{Nd}$ isotopic compositions (Fig. 4c). Besides, the basaltic rocks have generally lower ${ }^{87} \mathrm{Sr} /{ }^{86} \mathrm{Sr}$ and higher ${ }^{143} \mathrm{Nd} /{ }^{144} \mathrm{Nd}$ ratios than the andesites (Chen, 1989). The chemical and isotopic data demonstrate that this volcanism evolved in a tectonic environment affiliated with the western Ryukyu subducting system via combined crystal fractionation and assimilation processes (Chen, 1989; Chen, 1990).

Based on integration of available radiometric age data, Teng et al. (1992) pointed out a westward-younging character for the carc volcanism in the Northern Province. It appears that both the onset and the cessation of the volcanic activity migrated from the east to the west, hence each volcano was active only for a short period of about 1 million years. These authors proposed that the arc magmatism was initiated by the westerly encroachment of the Ryukyu subduction system, and ceased subsequently as a result of the southwestward propagation of the opening of the Okinawa Trough.

\section{Recent volcanisms in Northern Taiwan}

In northern Taiwan, two recent igneous centers provide important information concerning a change in the neotectonism. One is the Kueishantao, an offshore islet in the Okinawa Trough (Fig. 2). It may offer a unique opportunity for studying the initiation of backarc opening. The islet consists entirely of young andesitic rocks ( $<0.1 \mathrm{Ma}$; Juang, 1988 ), which seem to be characterized by similar geochemical features to the arc volcanics in northern Taiwan. They show LILE enrichment and HFSE depletion (Fig. 3d), which may reflect combined effects from subduction-related processes and crustal contamination (Chen, 1989). However, because of their relatively high $\mathrm{Sr}$ and low Nd isotopic compositions pointing towards the southeast China continental crust (Fig. 4d), crustal contamination could have played a significant role in magma geneses during the initial stage of opening of the Okinawa Trough. The degrees of 
crustal contamination may diminish following the establishment of the back-arc spreading, as evidenced by the lower $\mathrm{Sr}$ and higher $\mathrm{Nd}$ isotopic ratios of dredged volcanics (Fig. 4d) from the well-rifted region in the central Okinawa (Auzende et al., 1990).

The other recent volcanism took place in the Tsaolingshan, an independent volcanic dome sitting on the Pleistocene sediments in northwestern Taiwan (Fig. 2). It consists of mafic ultrapotassic rocks $\left(\mathrm{K}_{2} \mathrm{O} / \mathrm{Na}_{2} \mathrm{O}>2\right)$ extremely enriched in some LILE (Fig. 3d); hence these rocks have been termed "absarokites" (Yen, 1949; Chen, 1983). They used to be regarded as a variety of the arc volcanics in the Northern Province because of showing HFSE depletions (Fig. 3d), however, these magmas have distinctive chemical characteristics (e.g. $\mathrm{MgO} \approx 15 \%$; $\mathrm{P}_{2} \mathrm{O}_{5} \approx 1.5 \% ; \mathrm{K}_{2} \mathrm{O} \approx 4 \% ; \mathrm{Rb} \approx 1000 \mathrm{ppm}$ ) and somewhat higher $\mathrm{Sr}$ and lower $\mathrm{Nd}$ isotopic ratios (Fig. 4d). Furthermore, they were emplaced more recently ( $\leqslant 0.2 \mathrm{Ma}$; Juang, 1988), a significant distance away from the arc volcanic fields of the Northern Province.

We note that all of northern Taiwan has been stepping into the Okinawa Trough spreading regime; as evidenced by the Quaternary extensional structure features (Lee and Wang, 1988) and the carthquake focal mechanisms (Tsai et al., 1977; Tsai, 1986). Therefore, the emplacement of the ultrapotassic rocks may have resulted from the onset of this post-collisional extension. A comparable case exists in eastern Indonesia which has also been characterized by arc-continent collision (between the Banda arc and the Australian continent) since at least Pliocene time (Charlton, 1991). In that region, a post-collisional extensional setting has been generally accepted to account for the generation of highly potassic magmas of the late Quaternary age (Stolz et al., 1990;
Charlton, 1991; Edwards et al., 1991). In this sense, the chemical and isotopic characteristics of the Tsaolingshan absarokite can be explained to have originated from a refractory and metasomatized (phlogopite and apatite bearing) lithospheric mantle source recently modified by subduction-related processes.

\section{Tectonomagmatic Evolution of Taiwan}

Combining information provided by the igneous provinciality and the geotectonic history of Taiwan as discussed in the former sections, the tectonomagmatic evolution in Taiwan can be summarized as follows.

Since the early Tertiary the passive margin of southeastern China has been a rifted continental margin related to the opening of the South China Sea. The rifting lasted at least until the late Miocene and resulted in the formation of many sedimentary basins coupled with episodic intraplate basaltic volcanism (Fig. 5a). The Luzon volcanic arc, resulting from eastward subduction of the South China Sea plate underneath the Philippine Sea plate, did not have any contact with the rifted continent until about $12 \mathrm{Ma}$. Since then, northwestward motion of the Philippine Sea plate has given rise to the onset of the collision between the Luzon arc and the Asian continent. This collision changed the tectonic environment from dilational to compressional and hence terminated the intraplate basaltic volcanism (Fig. 5b).

The continuing collision resulted in folding and thrusting of the continental margin to form the orogen in Taiwan. At the latest Miocene, the northern tip of the Luzon arc began to encroach upon the southeastern China margin. This may have started the incorporation

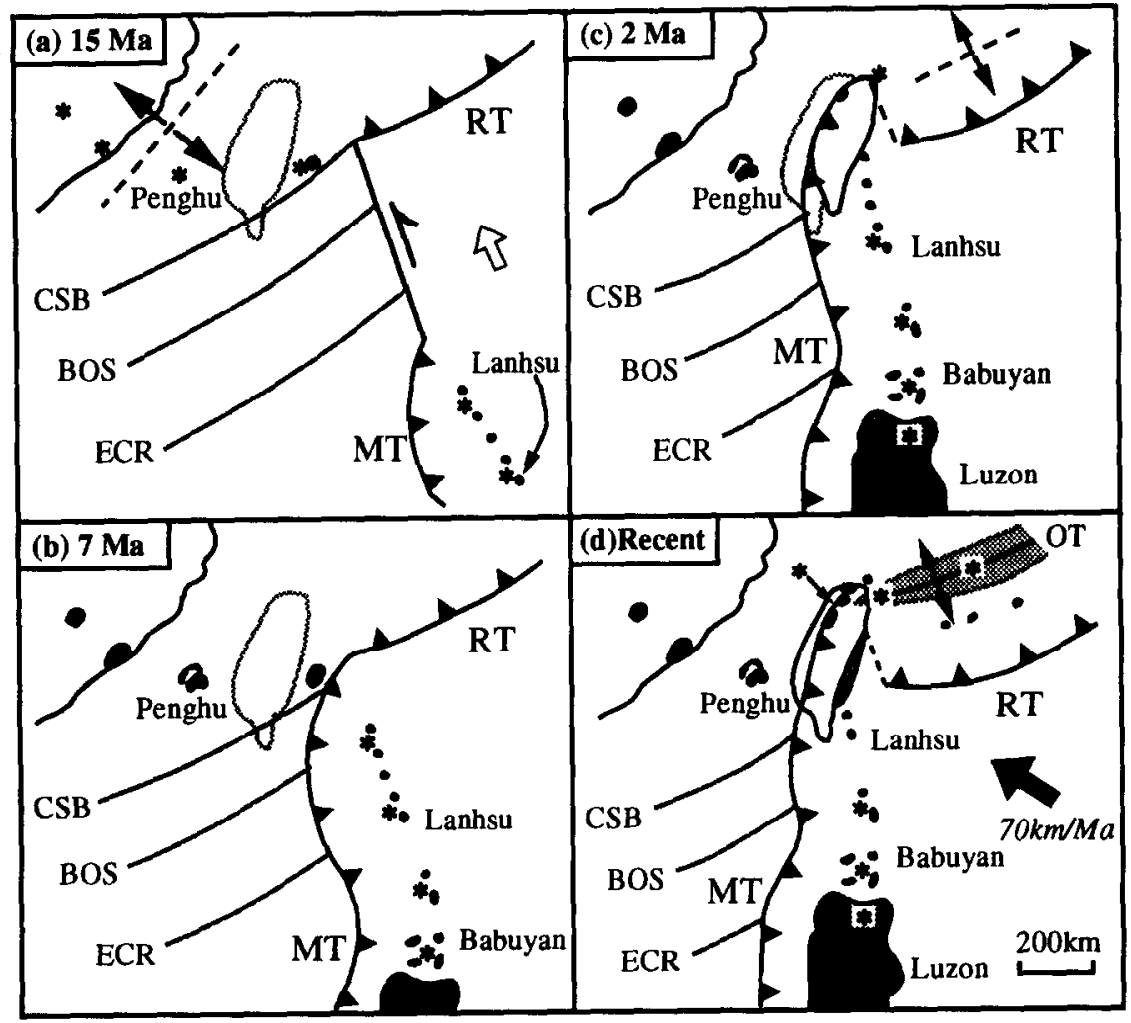

Fig. 5. Integrated maps modified from Teng (1990) showing the late Cenozoic tectonomagmatic evolution of Taiwan. Stars indicate active magmatisms at various ages. CSB $=$ continental shelf break; BOS = base of slope; $\mathrm{ECR}=$ edge of continental rise; $\mathrm{MT}=$ Manila Trench; OT = Okinawa Trough. 
of continental materials into the northern Manila Trench and influenced the arc magma generation, as evidenced by the temporal chemical and isotopic variation observed in the volcanic rocks of the Coastal Range. Following the movement of the overlying Luzon arc, the western boundary of the Phillippine Sea plate propagated to the west. Consequently, the compressional tectonism in the northern orogen ceased and the arc magmatism related to the southwestern Ryukyu Trench took place since about $3 \mathrm{Ma}$ (Fig. 5c). In the meantime, the collision also induced opening of the Okinawa Trough which subsequently obstructed the Ryukyu subduction regime and terminated the nascent arc volcanism (Fig. 5d). Relating to this back-arc opening, a post-collisional extension setting has been initiated most recently in northern Taiwan. It resulted in the Kueishantao volcanism in the southwestern part of the Okinawa Trough and the emplacement of Tsaolingshan ultrapotassic rocks in northwestern Taiwan.

Acknowledgements - We are grateful to Dr U. Knittel for his continual encouragement during the preparation of this paper. S. L. Chung sincerely thanks Professor B. M. Jahn and his colleagues in Rennes who provided much spiritual and material support. Comments from B. M. Jahn, U. Knittel, S.-s. Sun and U. Uto are appreciated. This study has benefitted from the financial support of the National Science Council (Taiwan) through research grants NSC81-0202-M002-12 and NSC83-0202-M002-006.

\section{REFERENCES}

Auzende J., Boespflug X., Bougault H., Dosso L., Foucher J., Joron J., Ruellan E. and Sibuet J. (1990) From intracratonic extension to mature spreading in back arc basins: examples from the Okinawa Lau and north Fiji basins. Oceanol. Acta 10, 153-163.

Bowin C., Lu R. S., Lee C. S. and Schouten H. (1978) Plate convergence and accretion in Taiwan-Luzon region. Bull. Am. Asso Petrol. Geol. 62, 1645-1672.

Chai B. H. T. (1972) Structure and tectonic evolution of Taiwan. Am. J. Sci. 272, 389-442.

Chang M. D. and Chen J. C. (1979) Geochemistry of andesites from kueishantao. Acta Oceanogr. Taiwan 9, 39-49.

Charlton T. R. (1991) Postcollision extension in arc-continent collision zones, eastern Indonesia. Geology 19, 28-31.

Chen Chang-Hwa (1989) Nd-Sr-O isotopic study of Cenozoic are volcanic rocks in Taiwan. Ph.D. thesis, National Taiwan University, Taipei (in Chinese).

Chen Chang-Hwa, Shieh Y. N., Lee T., Chen C.-H. and Mertzman S. A. (1990) $\mathrm{Nd}-\mathrm{Sr}-\mathrm{O}$ isotopic evidence for source contamination and an unusual mantle component under Luzon arc. Geochim. Cosmochim. Acta 54, 2473-2483.

Chen Cheng-Hong (1978) Petrochemistry and origin of Pleistocene volcanic rocks from northern Taiwan. Bull. Volcanol. 4I, 513-528.

Chen Cheng-Hong (1983) The geochemicam evolution of Pleistocene absarokite, shoshonite and high-alumina basalt in northern Taiwan. Mem. Geol. Soc. China 5, 85-96.

Chen Cheng-Hong (1990) The igneous rocks of Taiwan. Cent. Geol., Geol. Taiwan Series 1, $137 \mathrm{pp}$. (in Chinese).

Chen Cheng-Hong and Chung S. L. (1985) Petrology and geochemistry of Neogene basalts and related rocks in northern Taiwan: (1) basanitoids, alkali olivine basalts and tholeiites from KunahsiChutung area. Acta Geol. Taiwan 23, 35-62.

Chen Cheng-Hong, Jahn B. M., Lee T., Chen C. H. and Cornichet J. (1990) Sm-Nd isotopic geochemistry of sediments from Taiwan and implications for the tectonic evolution of southeast China. Chem. Geol. 88, 317-332.
Chen S. J. (1988) Isotope and trace element geochemistry of the Neogene basalts from western Taiwan. Masters thesis, National Taiwan University, Taipei (in Chinese).

Chung S. L. and Sun S.-s. (1992) A new genetic model for the East Taiwan Ophiolite and its implications for Dupal domains in the northern hemisphere. Earth Planet. Sci. Lett. 109, 133-145.

Chung S. L., Sun S.-s., Tu K., Chen C.-H. and Lee C. Y. (1994). Late Cenozoic basaltic volcanism around the Taiwan Strait, SE China product of lithosphere-asthenosphere interaction during continental extension. Chem. Geol. 112, 1-20.

Chung S. L., Jahn B. M., Chen S. J., Lee T. and Chen C.-H. (1995) Miocene basalts in NW Taiwan: evidence for EM-type mantle sources in the continental lithosphere. Geochim. Cosmochim. Acta 59, 549-555.

Dahlen F. A., Suppe J. and Davies D. (1984) Mechanisms of fold-andthrust belts and accretionary wedges: cohesive Colomb theory. I. Geophys. Res. 89, 10087-10101.

Defant M. J., Maury R. C., Joron J., Feigenson M. D.. Letterrier J., Bellon H., Jacques D. and Richard M. (1990) The geochemistry and tectonic setting of the northern section of the Luzon are (the Philippines and Taiwan). Tectonophysics. 183, 187-205.

Edwards C., Menzies M. A. and Thirlwall M. (1991) Evidence from Muriah, Indonesia, for the interplay of supra-subduction zone and intraplate processes in the genesis of potassic alkaline magmas J. Petrol. 32, 555-592.

Hickey-Vargas R. (1991) Isotope characteristics of submarine lavas from the Philippine Sea: implications for the origin of arc and basin magmas of the Philippine tectonic plate. Earth Planet. Sci. Lett. 107, 290-304.

Ho C. S. (1982) Tectonic evolution of Taiwan: explanatory text for the tectonic map of Taiwan. Ministry for Economic Affairs, Taipei, $126 \mathrm{pp}$.

Ho C. S. (1986) A synthesis of the geologic evolution of Taiwan. Tectonophysics. 125, 1-16.

Jahn B. M. (1986) Mid-ocean ridge or marginal basin origin of the East Taiwan Ophiolite: chemical and isotopic evidence. Contrib. Mineral. Petrol. 92, 194-206.

Juang W. S. (I988) Geochronology and chemical variations of late Cenozoic volcanic rocks in Taiwan. Ph.D. thesis. National Taiwan University, Taipei (in Chinese).

Juang W. S. and Bellon H. (1984) The potassium-argon dating of andesites from Taiwan. Proc. Geol. Soc. China 27, 86-100.

Juang W. S. and Chen J. C. (1989) Geochronology and geochemistry of volcanic rocks in northern Taiwan. Bull. Cent. Geol. Surt. 5 , $31-66$.

Lan C. Y. (1989) Chronology and petrogenesis of Taiwan gneisses. Ph.D. thesis, National Taiwan University, Taipei (in Chinese).

Lee C. T. and Wang Y. (1988) Quaternary stress changes in northern Taiwan and their tectonic significance. Proc. Geol. Soc. China 31, 154-168

Lee C. Y. (1990) Peleogeographic reconstruction of the late Miocene Penghu Islands. Geol. Soc. China Annual Meeting, Abstr. Vol. p. 24

Liou J. G., Lan C. Y., Suppe J. and Ernst W. G. (1977) The East Taiwan Ophiolite: its occurrence, petrology, metamorphism and tectonic setting. MRSO spec. Report 1, 212 pp.

Liu T. K. and Wang Y. (1982) Expression and petrochemical implications of the western egde of the subducted Philippine Sea plate underneath Taiwan. Acta Geol. Taiwan 21, 221-229

Lo C. H., Onstott T. C., Chen C. H., and Lee T. (1994) An assessment of ${ }^{40} \mathrm{Ar} /{ }^{39} \mathrm{Ar}$ dating for the whole rock volcanic samples from the Luzon arc near Taiwan. Chem. Geol. 114, 157-178.

McDermott, F., Defant M. J., Hawkesworth C. J., Maury R. C. and Joron J. L. (1993). Isotope and trace element evidence for three component mixing in the genesis of North Luzon are lavas (Philippines). Contrib. Mineral. Petrol. 113, 9-23.

Ru K. and Piggot J. D. (1986) Episodic rifting and subsidence in the South China Sea. Bull. Am. Assoc. Petrol. Geol. 70, 1136-1155.

Seno R. and Maruyama S. (1984) Paleogeographic reconstructions and origin of the Philippine Sea. Tectonophysics 102, 53-84

Shih C. Y., Sun S.-s., Liou J. G., Yen T. P., Rhodes J. M., and Hsu I. C. (1972) Petrology and geochemistry of the coastal range Ophiolite of Taiwan. EOS 53, 535 
Stolz A. J., Varne R., Davies G. R., Wheller G. E. and Foden J. D. (1990) Magma source components in an arc-continent collision zone: the Flores-Lembata sector, Sunda arc, Indonesia. Contrib. Mineral Petrol. 105, 585-601.

Sun S. C. (1985) The Cenozoic tectonic evolution of offshore Taiwan. Energy 10, 421-432.

Sun S. C. and Hsu Y. Y. (1991) Overview of the Cenozoic geology and tectonic development of offshore and onshore Taiwan. TAICRUST Workshop Proc., Taipei, pp. 35-48.

Sun S.-s. and McDonough W. F. (1989) Chemical and isotopic systematics of oceanic basalts: implications for mantle composition and processes. In Magmatism in the Ocean Basins (Edited by A. D. Sanders and M. J. Norry), pp. 313-345. Geological Society, London Special Publication 42.

Suppe J. (1981) Mechanics of mountain-building and metamorphism in Taiwan. Mem. Geol. Soc. China 4, 67-90.

Suppe J. (1984) Kinematics of arc-continent collision, flipping of subduction, and back-arc spreading near Taiwan. Mem. Geol. Soc. China 6, 21-34.

Suppe J., Liou J. G. and Ernst W. G. (1981) Paleogeographic origins of the Miocene East Taiwan Ophiolite. Am. J. Sci. 281, 228-246.

Taylor B. and Hayes D. E. (1980) The tectonic evolution of the South China Basin. In The Tectonic and Geologic Evolution of Southeast Asian Seas and Islands (Edited by D. E. Hayes), pp. 89-104. AGU Geophysical Monograph 23.

Teng L. S. (1987) Tectonostriatigraphic facies and geologic evolution of the Coastal Range, eastern Taiwan. Mem. Geol. Soc. China 8, 229-250.

Teng L. S. (1990) Geotectonic evolution of late Cenozoic arc-continent collision in Taiwan. Tectonophysics 183, 57-76.

Teng L. S., Wang Y., Tang C. H., Huang C. Y., Huang T. C., Yu M. S. and Ke A. (1991) Tectonic aspect of the Paleogene depositional basin of northern Taiwan. Proc. Geol. Soc. China 34, 313-336.

Teng L. S., Chen C.-H., Wang W. S., Liu T. K., Juang W. S. and Chen J. C. (1992) Plate kinematic model for late Cenozoic arc magmatism in northern Taiwan. J. Geol. Soc. China 35, 1-18.
Tsai Y. B. (1986) Seisomotectonics of Taiwan. Tectonophysics 125, $17-38$.

Tsai Y. B., Teng T. L., Chiu J. M. and Liu H. L. (1977) Tectonic implications of the seismicity of the Taiwan region. Mem. Geol. Soc. China 2. 13-42.

Tu K., Flower M. F. J., Carlson R. W., Zhang M. and Xie G. H. (1991) $\mathrm{Sr}, \mathrm{Nd}$, and $\mathrm{Pb}$ isotopic compositions of Hainan basalts (south China): implications for a subcontinental lithosphere Dupal source. Geology 19, 567-569.

Tu K., Flower M. F. J., Carlson R. W. Xie G. H., Chen C.-Y. and Zhang M. (1992) Magmatism in the South China Basin, 1. Isotopic and trace element evidence for an endogenous Dupal mantle component. Chem. Geol. 97, 47-63.

Wang W. S. and Chen C.-H. (1990) The volcanology and fission track age dating of pyroclastic deposits in Tatun Volcano Group, northern Taiwan. Acta Geol. Taiwan 28, 1-30.

Yang T. Y. (1992) Magma evolution of north Luzon arc and the tectonic implication. Ph.D. thesis, National Taiwan University, Taipei (in Chinese).

Yang T. Y., Liu T. K. and Chen C.-H. (1988) Thermal event records in the Chimei igneous complex: constraint on the ages of magma activies and the structural implication based on fission track dating. Acta Geol. Taiwan 26, 237-246.

Yang T. Y., Chen C.-H. and Lee T. (1992) Fission track dating of Lutao volcanics: implications of partial annealing and eruption history. J. Geol. Soc. China 35, 19-44.

Yen T. P. (1949) A preliminary study on the alkaline basalt of Tsaolingshan, Tachi, Sinchu, Taiwan. Bull. Geol. Surv. Taiwan 2, 1-23.

Yen T. P. (1958) Cenozoic volcanic activity in Taiwan. Taiwan Min. Indust. 10, 1-39.

Zhou X. M. and Chen T. H. (1981) Composition and evolution of Cenozoic basaltic rocks in southeastern coastal provinces in China. Acta Geol. Sin. 55, 29-40 (in Chinese).

Zindler A. and Hart S. R. (1986) Chemical geodynamics. A. Rev. Earth Planet. Sci. 14, 493-571. 